\title{
Erratum: The basic leucine zipper transcription factor E4BP4 is essential for natural killer cell development
}

Duncan M Gascoyne, Elaine Long, Henrique Veiga-Fernandes, Jasper de Boer, Owen Williams, Benedict Seddon, Mark Coles, Dimitris Kioussis \& Hugh JM Brady

Nat. Immunol. 10, 1118-1124 (2009); published online 13 September 2009; corrected after print 5 October 2009

In the version of this article initially published, the equal contribution of Duncan M. Gascoyne and Elaine Long is not noted. The error has been corrected in the HTML and PDF versions of the article.

\section{Erratum: TCR and Lat are expressed on separate protein islands on T cell membranes and concatenate during activation}

Björn F Lillemeier, Manuel A Mörtelmaier, Martin B Forstner, Johannes B Huppa, Jay T Groves \& Mark M Davis

Nat. Immunol. 11, 90-96 (2010); published online 13 December 2009; corrected after print 29 January 2010

In the version of this article initially published, some rows in Table 1 were misaligned. The error has been corrected in the HTML and PDF versions of the article.

\section{Corrigendum: Toll-like receptor 2 on inflammatory monocytes induces type I interferon in response to viral but not bacterial ligands}

\author{
Roman Barbalat, Laura Lau, Richard M Locksley \& Gregory M Barton \\ Nat. Immunol. 10, 1200-1207 (2009); published online: 4 October; corrected after print 11 November 2009
}

In the version of this article initially published, the label along the vertical axis of the top row in Figure 6a is incorrect. The correct label should be Ly6G, and the related text in the legend should read "Numbers adjacent to outlined areas indicate $\mathrm{Ly}_{6} \mathrm{G}^{+} \mathrm{CD} 11 \mathrm{~b}^{+}$cells $\left(\right.$top row) or $\mathrm{Ly} 6 \mathrm{C}^{+} \mathrm{CD} 11 \mathrm{~b}^{+}$ cells (bottom row)." The error has been corrected in the HTML and PDF versions of the article.

\section{Corrigendum: MicroRNA miR-326 regulates $\mathrm{T}_{\mathrm{H}^{-}} 17$ differentiation and is associated with the pathogenesis of multiple sclerosis}

Changsheng Du, Chang Liu, Jiuhong Kang, Guixian Zhao, Zhiqiang Ye, Shichao Huang, Zhenxin Li, Zhiying Wu \& Gang Pei

Nat. Immunol. 10, 1252-1259 (2009); published online 18 October 2009; corrected after print 4 December 2009

In the version of this article initially published, the Actin loading control blot for the top blot is missing from Figure $5 \mathrm{c}$. The error has been corrected in the HTML and PDF versions of the article.

\section{Corrigendum: Immunological synapse formation inhibits, via NF-kB and FOXO1, the apoptosis of dendritic cells}

Lorena Riol-Blanco, Cristina Delgado-Martín, Noelia Sánchez-Sánchez, Luis M Alonso-C, María Dolores Gutiérrez-López, Gloria Martínez del Hoyo, Joaquín Navarro, Francisco Sánchez-Madrid, Carlos Cabañas, Paloma Sánchez-Mateos \& José Luis Rodríguez-Fernández Nat. Immunol. 10, 753-760 (2009); published online 7 June 2009; corrected after print 11 February 2010

In the version of this article initially published, a citation was omitted. It should be cited in the third paragraph of the Discussion section after the second sentence as follows: In this context, it has been suggested that Notch1, another receptor located at the IS(DC), may inhibit the apoptosis of DCs by inducing activation of Akt and STAT3, a transcription factor that promotes cell survival51. The bibliographic information is as follows: 51. Luty, W.H., Rodeberg, D., Parness, J. \& Vyas, YM. Antiparallel segregation of notch components in the immunological synapse directs reciprocal signaling in allogeneic Th:DC conjugates. J. Immunol. 179, 819-829 (2007). The error has been corrected in the HTML and PDF versions of the article. 